\title{
POST-ENACTMENT LEGISLATIVE SIGNALS
}

\author{
WILliam N. ESKRIDGE, JR.*
}

\section{INTRODUCTION}

Lawyers emphasize original legislative expectations when they talk about statutory interpretation. The lawyer's perspective is inspired by concern for the rule of law and by anxiety over policymaking by unelected officials. These concerns do not dictate the static assumptions lawyers draw from them, however. ${ }^{1}$ More importantly, traditional theories of legal interpretation project a vision of government decisionmaking as essentially discontinuous acts made by wooden and isolated institutions. Lawyers ought to rethink this vision in light of other theories regarding the operation of the legislature.

Positive political theory ("PPT") $)^{2}$ views statute making as a continuous process, an institutional process, a necessarily dynamic process. Congress, the president, and the judiciary each have goals and policy preferences which they seek to implement. The institutions that seek to impose their preferences within the constraints of defined roles interact in a dynamic process of statutory lawmaking. Congress enacts the statute, the president or an independent agency implements and interprets the statute, courts review the executive implementation and interpretation, and Congress considers statutory amendments in response to implementations and interpretations by the other two branches. The policymaking process is a spiral of institutional competition and cooperation.

Statutory interpretation, considered from the perspective of PPT, yields a number of iconoclastic conclusions. ${ }^{3}$ In this new tradition, Professors Schwartz, Spiller, and Urbiztondo suggest that judges pay attention to legislative history, not because of rule-of-law or legitimacy concerns, but because of their own institutional desire not to be overridden by Congress for reading their prefer-

Copyright $\odot 1994$ by Law and Contemporary Problems

* Professor of Law, Georgetown University Law Center.

1. See William N. Eskridge, Jr., Dynamic Statutory Interpretation, 135 U. PA. L. REV. 1479 (1987).

2. For an introduction to this genre of scholarship, see Symposium, Positive Political Theory and Public Law, 80 GEO. L.J. 457 (1992), especially Daniel A. Farber \& Philip P. Frickey, Foreword: Positive Political Theory in the Nineties, 80 GEO. L.J. 457 (1992).

3. The earliest application of this approach to issues of statutory interpretation was Brian Marks, A Model of Judicial Influence on Congressional Policymaking: Grove City College v. Bell (1989) (unpublished $\mathrm{Ph}$.D. dissertation Washington University). Later applications include William N. Eskridge, Jr., Reneging on History? Playing the Court/Congress/President Civil Rights Game, 79 CAL. L. REV. 613 (1991); John Ferejohn \& Barry Weingast, Limitation of Statutes: Strategic Statutory Interpretation, 80 GeO. L.J. 565 (1992); Rafael Gely \& Pablo T. Spiller, A Rational Choice Theory of Supreme Court Statutory Decisions, with Applications to the State Farm and Grove City Cases, 6 J.L. ECON. \& ORG. 263 (1991). 
ences into statutes. ${ }^{4}$ Under this regime, Congress has incentives to send credible signals to the Supreme Court. Schwartz, Spiller, and Urbitztondo suggest that Congress sends its clearest signals when it is very concerned about an issue of statutory interpretation and when the costs of overriding a contrary interpretation are relatively low (when, for example, there is a consensus on the issue within Congress). The Court will attend to these sorts of legislative signals when examining a statute, even if its own preferences would suggest another interpretation or if the signals come after the statute has been enacted. The hypothesis of the article needs a more sophisticated model of judicial preferences, but as modified it would present a robust positive theory of the Burger Court's extraordinary reliance on post-enactment legislative signals. On the other hand, the Schwartz, Spiller, and Urbiztondo model does not present a robust positive theory of the Rehnquist Court's decisions.

\section{A Model of Judicial Preferences and the Relevance of Post- ENACTMENT LEGISLATIVE SIGNALS}

Lawyers believe that courts are primarily concerned with enforcing and following the rule of law when they interpret statutes. Positive political theorists tend to believe that courts are primarily concerned with reading their own preferences into statutes, to the extent they can do so while avoiding congressional overrides. ${ }^{5}$ These views are not as inconsistent as they appear. ${ }^{6}$

On the one hand, positive political theorists cannot exclude rule-of-law considerations from their models. Assuming, as PPT does, that courts seek to impose their own preferences on statutes to the extent they can without being overridden, one still needs a theory of judicial preferences. Although there is extensive literature on congressional and presidential preferences, there is no generally accepted theory of judicial preferences. Yet there is good reason to believe that judicial preferences are not formed in the same way as congressional or presidential preferences. Because federal (and many state) judges have life tenure, and hence are not anxious about fundraising for reelection campaigns, they are not subject to the influence of organized interest groups as are Congress and the president. Although judges may have policy preferences that influence their readings of statutes, judicial preference for coherence in the law is more important in a large majority of cases. A judge will prefer interpretations that accord with professionally accepted ways (canons) of reading statutory texts, other provisions of the statute, other statutes, statutory precedents, the common

4. Edward P. Schwartz et al., A Positive Theory of Legislative Intent, 57 LAW \& CONTEMP. PROBS. 51,54 (Winter 1994).

5. See William N. Eskridge, Jr., Overriding Supreme Court Statutory Interpretation Decisions, 101 YALE L.J. 331, 390-403 (1991); John Ferejohn \& Charles Shipan, Congressional Influence on Bureaucracy, 6 J.L. ECON. \& ORG. 1 (Special Issue 1990).

6. See generally Ferejohn \& Weingast, supra note 3, at 570-82 (explaining ways to resolve the tension between democratic and rule-of-law concerns). 
law, and constitutional law. Judicial preference for coherence is found not only in nonbinding judicial pronouncements to that effect, but also in the numerous cases in which judges have interpreted statutes strongly against their known preferences and with every expectation that Congress would not override their result. In these cases, it is clear that the judges felt constrained by coherence (rule-of-law) concerns.

Consider Griffin v. Oceanic Contractors, Inc. ${ }^{7}$ Danny Griffin, a welder working on Oceanic's vessels in the North Sea, was injured during his employment and subsequently discharged. Oceanic withheld $\$ 412.50$ in earned wages that Griffin claimed were owed to him, and he brought suit under a federal statute that required certain maritime employers to pay wages within a specified period following termination of a seaman's employment. The statute further provided: "Every master or owner who refuses or neglects to make payment in the manner hereinbefore mentioned without sufficient cause shall pay to the seaman a sum equal to two days' pay for each and every day during which payment is delayed beyond the respective periods." 8 The trial court found Oceanic liable for the withheld wages and assessed the penalty for the period between discharge (April 1, 1976) and Griffin's reemployment (May 5, 1976); the penalty amounted to $\$ 6,881.60 .^{9}$ The Supreme Court directed that the penalty had to be recalculated to reflect the period between the seaman's discharge and the actual date of payment (which was not until after the trial court's judgment). Justice Rehnquist's opinion for the Court relied on the literal terms of the statute, which said that the owner "shall pay" penalty wages "for each and every day during which payment is withheld." No exceptions appeared on the face of the statute. Hence, by the Court's calculations, the penalty for withholding $\$ 412.50$ became $\$ 302,790.40$. $^{10}$

This interpretation provided a lavish windfall to the seaman and sets up odd incentives for seamen and shipowners in this situation. It is doubtful that Justice Rehnquist and at least some of the other Justices in the majority were sympathetic to such windfall recoveries. Although Justice Rehnquist included boilerplate language about Congress's ability to amend the statute to correct this obvious inefficiency, Congress rarely overrides the Court in matters of labormanagement relations, because such issues are highly conflictual. Thus, there has been no discernible effort to override Griffin. ${ }^{11}$ Yet Justice Rehnquist was

7. 458 U.S. 564 (1982).

8. 46 U.S.C. $\$ 596$ (repealed 1983).

9. Griffin, 458 U.S. at 564.

10. Id. at 579 .

11. In 1983, Congress rewrote the double wages provision, as part of a general recodification. See Shipping Enactment, Pub. L. No. 98-89, 97 Stat. 566 (1983) (codified at 46 U.S.C. $\$ 10313(\mathrm{~g})(1988)$ ).

The House committee report suggested that

the literal language of the statute should control the disposition of the cases. There is no mandate in logic or in case law for reliance on legislative history to reach a result contrary to the plain meaning of the statute, particularly where that plain meaning is in no way unreasonable.

H.R. REP. No. 338, 98th Cong. 1st Sess. 120 (1983), reprinted in 1983 U.S.C.C.A.N. 932. 
probably quite comfortable interpreting the statute in this way, because he has internalized the judicial norm that clear texts should be interpreted according to their plain meaning unless such interpretation would render the statute unconstitutional or absurd. As this example illustrates, political theorists need to consider coherence (rule-of-law) concerns in constructing their theory of judicial preferences.

On the other hand, rule-of-law values do not exhaust the preferences that are relevant to statutory interpretation. Traditional sources of legal interpretation often support more than one interpretation of a statute, giving interpreters lawmaking discretion. ${ }^{12}$ When exercising that discretion, judges typically consider how a "reasonable" lawmaker might have intended the statute to be interpreted. ${ }^{13}$ The judges will consider a variety of factors, including his or her own preferences (what would I do?) and the preferences of the current legislature (how would the legislature answer the question today?). To figure out the preferences of the current legislature, the Court might consider legislative history. As Schwartz, Spiller, and Urbiztondo suggest, statements in committee reports and by key players in the legislature can signal both intensity and consensus in Congress on a certain issue. A Court interested in either rule-oflaw values or reading its own policy preferences into statutes would attend carefully to such statements.

When the legislative history is clear and the statutory text is equally clear, then the job of interpretation is an easy one. The more interesting cases are those where neither the statutory text nor the original legislative history anticipates the interpretive issue before the Court. These challenging cases recur and tend to multiply as societal and legal circumstances change over time. ${ }^{14}$ Although the original legislative history remains relevant in such cases, ${ }^{15}$ Schwartz, Spiller, and Urbiztondo suggest that courts will be interested in signals sent by later Congresses, including statements by relevant committees and key legislators setting forth their understanding of how the statute should be construed. The authors suggest that such subsequent legislative history will be most persuasive to the Court when the history reflects intense legislative interest

12. See H.L.A. HART, THE CONCEPT OF LAW (1961).

13. See Henry M. Hart, JR. \& Albert M. SACKS, The Legal Process: Basic Problems in THE MAKING AND APPLICATION OF LAW 1200, 1414-15 (tent. ed. 1958).

14. They recur and multiply for a number of reasons: (1) Society responds to the statute in ways that Congress cannot predict; over time the problems targeted by Congress are solved or go away, and new versions of the problem arise. (2) Some or all of the assumptions originally made by Congress turn out to be not completely true; false assumptions create fact situations and equitable conflicts Congress would not have considered. (3) New legal developments, including new statutes and constitutional decisions, often influence the reasonableness of certain statutory interpretations and press the earlier statute in directions the enacting Congress would not have expected. See William N. Eskridge, Jr., Spinning Legislative Supremacy, 78 GEO. L.J. 319 (1990).

15. For example, the congressional purpose suggested by the legislative history is a means by which interpreters can adapt the statute to circumstances not precisely anticipated by the enacting legislature. See HART \& SACKS, supra note 13, at 1203-15; Felix Frankfurter, Some Reflections on the Reading of Statutes, 47 COLUM. L. REV. 527 (1947). 
in the issue and little potential opposition to a statutory override of contrary judicial interpretations.

\section{II}

\section{THE BuRger COURT'S RELIANCE ON POST-ENACTMENT LEGISLATIVE SIGNALS}

The hypothesis that the Supreme Court will be interested in post-enactment legislative signals of intense interest and low override costs is borne out by the Burger Court's statutory decisions. The Burger Court was often willing to consider post-enactment legislative signals, usually read the signals astutely, and was rarely overridden when subsequent Congresses sent cogent signals of their interest in an issue. The Court's willingness to consider post-enactment signals provides a useful way to conceptualize the Burger Court's approach to these doctrines of statutory interpretation.

\section{A. Subsequent Legislative History}

Subsequent legislative history has little or no formal relevance to original legislative intent or statutory plain meaning and is accordingly viewed with suspicion under traditional doctrines of statutory interpretation. ${ }^{16}$ Although the Burger Court accepted the traditional view that "the views of a subsequent Congress form a hazardous basis for inferring the intent of an earlier one,"'17 the Court also believed that "such views are entitled to significant weight and particularly so when the precise intent of the enacting Congress is obscure."18 Consistent with a theory of post-enactment legislative signals, the Burger Court was much more likely to treat subsequent legislative history as probative when that history reflected intense interest and consensus on that issue in recent Congresses.

For example, in United States v. Board of Commissioners of Sheffield, Alabama, ${ }^{19}$ the Court interpreted section 4 of the Voting Rights Act of $1965^{20}$ to apply to municipalities on the ground that they were "political subdivisions" of states, explicitly covered in section 4 . The dissent made a strong case that the Court's reading was not the plain meaning of the statute, was inconsistent with the statutory structure, and was contrary to specific legislative expectations in 1965 that "political subdivisions" would be narrowly construed. ${ }^{21}$ Justice Brennan's opinion for the Court did not refute these rule-of-law arguments, but

16. See Reed Dickerson, Statutory Interpretation: Dipping into Legislative History, 11 HOFSTRA L. REV. 1125 (1983).

17. Consumer Prod. Safety Comm'n v. GTE Sylvania, Inc., 447 U.S. 102, 117-18 (1980) (quoting United States v. Price, 361 U.S. 304, 313 (1960)).

18. Seatrain Shipbuilding Corp. v. Shell Oil Co., 444 U.S. 572, 596 (1980) (citing NLRB v. Bell Aerospace Co., 416 U.S. 267, 275 (1974)).

19. 435 U.S. 110,118 (1978).

20. 79 Stat. 438 (codified as amended at 42 U.S.C. $\$ 1973($ b) (1988 \& Supp. V)).

21. 435 U.S. at $140-50$ (Stevens, J., dissenting). 
relied instead upon signals that Congress in the 1970s supported a broad reading of section $4 .^{22}$ That evidence suggested specific and relatively intense congressional interest in the issue. By 1975, even critics of the Act believed it applied to municipalities, suggesting to at least some Justices the likelihood of an override if the Court interpreted the statute narrowly. ${ }^{23}$

Sheffield can be contrasted to the "snail darter case," TVA v. Hill. ${ }^{24}$ In $T V A$, the Court interpreted the Endangered Species $\mathrm{Act}^{25}$ to halt the construction of a multimillion dollar dam. The Court based its decision upon the broad statutory language and specific legislative history of the recently enacted statute which indicated that Congress strongly desired the protection of endangered species to be accomplished without regard to cost. ${ }^{26}$ The Court rejected TVA's argument that continued appropriations for the dam and specific exempting language in reports by appropriations committees in both the House and Senate indicated a legislative intent to allow construction of almost-completed dams to go forward. ${ }^{27}$ This case can be seen as one in which Congress sent mixed signals: Before the statute was enacted, the sponsors of the statute and the substantive committee reports signaled a strong commitment to broad enforcement of the statute-whereas after it was enacted, the appropriations committee's reports signaled a willingness to permit exceptions to the statute's prohibitions. The Court's decision in TVA suggests that in a case of mixed signals, particularly where the later signals are not from substantive committees, rule-of-law considerations will be determinative in the Court's interpretation of a statute.

\section{B. Legislative Inaction as a Ratification of Statutory Precedents}

The theory of post-enactment legislative signals also provides a way to explain the Burger Court's approach to statutory precedents. Once a court or an agency had authoritatively interpreted a statute, the Burger Court was often willing to treat those past interpretations as binding on the current Court, even when they were in strong tension with other rule-of-law values. The Court usually explained its deference by relying on Congress's inaction: Because Congress had not overridden the precedents, they should be treated as having

22. Justice Brennan cited specific evidence in the hearings, as well as in both House and Senate committee reports, that by 1975 the key legislative players assumed that section 4 included municipalities. Id. at 133-34 (opinion for the Court). Although this was "original" legislative history for the 1975 reenactment of the Voting Rights Act, it was "subsequent" legislative history for the 1965 and 1970 versions under which the case was brought.

23. Justices Brennan and Marshall probably favored liberal readings of the Voting Rights Act as a matter of their own ideology. But moderate Justices Stewart, White, Blackmun, and Powell (or some of the four) would probably have followed the rule-of-law arguments of Justice Stevens' dissent (joined by Chief Justice Burger and Justice Rehnquist) if Congress's post-enactment signals had not been so strong.

24. 437 U.S. 153 (1978).

25. Pub. L. No. 93-205, 87 Stat. 884 (1973) (codified at 16 U.S.C.A. $\$ \S 1531-1544$ (1988)).

26. Hill, 437 U.S. at 173-93.

27. Brief for Hill at 7-18, Hill (No. 76-1701). 
been ratified after the fact. Academics have been scornful of the Court's practice on the ground that it rests upon an unrealistic view of the legislative process, ${ }^{28}$ but the theory of post-enactment legislative signals suggests a way to understand the Court's practice.

Perhaps the most criticized case invoking stare decisis for statutory precedents and the legislative inaction doctrine is Flood v. Kuhn. ${ }^{29}$ A badly divided Court refused to overrule its fifty-year-old decision ${ }^{30}$ exempting major league baseball from the Sherman Act. Although rule-of-law values forcefully supported overruling the precedent, the Court was reluctant to do so "when Congress, by its positive inaction, ha[d] allowed those decisions to stand for so long and, far beyond mere inference and implication, ha[d] clearly evinced a desire not to disapprove them legislatively." ${ }^{31}$ The Court was in fact relying, not on mere inaction, but on post-enactment legislative signals that baseball should be exempt from antitrust laws. Dozens of bills dealing with sports and antitrust were introduced in Congress between 1957 and 1965. ${ }^{32}$ Almost all of the bills would have expanded baseball's exemption to other professional sports, as did the two bills that passed one chamber or the other (the House in 1958, the Senate in 1965). ${ }^{33}$ The failure of these bills to become laws was a signal not just that Congress was aware of baseball's unique position, but also that there may have been a consensus in favor of exemption. Although these signals were not as powerful as those in, for example, Sheffield, they were strong enough to save the exemption, given the feelings of some members of the Court that baseball should receive special treatment. ${ }^{34}$

Stronger post-enactment signals explain another controversial Burger Court decision, Bob Jones University v. United States. ${ }^{35}$ In 1970-71, the Internal Revenue Service reinterpreted the tax code's exemption for "educational" institutions as inapplicable to schools (like Bob Jones) that discriminated on the basis of race. ${ }^{36}$ Although this administrative interpretation was arguably inconsistent with the statute's plain meaning, a virtually unanimous ${ }^{37}$ Court followed the agency's interpretation. ${ }^{38}$ Chief Justice Burger's opinion for the Court emphasized post-enactment legislative signals, specifically deliberation in

28. See REED DiCKERSON, THE INTERPRETATION AND APPLICATION OF STATUTES (1975); Frank H. Easterbrook, Stability and Reliability in Judicial Decisions, 73 CORNELL L. REV. 422 (1988); William N. Eskridge, Jr., Overruling Statutory Precedents, 76 GEO. L.J. 1361 (1988); Earl Maltz, The Nature of Precedent, 66 N.C. L. REV. 367 (1988).

29. 407 U.S. 258 (1972).

30. Federal Baseball Club v. National League, 259 U.S. 200 (1922).

31. Flood, 407 U.S. at 283-84.

32. Brief for Respondents at 32-36, Flood (No. 71-32).

33. Id.

34. See Bob Woodward \& SCOTt ARMSTRONG, THE BRETHREN: INSIDE THE SUPREME COURT 223-26 (1979).

35. 461 U.S. 574 (1983).

36. Id. at $578-79$.

37. Id. at 612-14 (Rehnquist, J., dissenting) Rehnquist, the lone dissenter, argued for an interpretation consistent with the plain meaning of the statute.

38. Id. at 605 (opinion of the Court). 
congressional committee hearings about the agency's interpretation, rejection of specific amendments to override the agency, and a statutory expansion of the agency's view to deny tax exemptions to social clubs that discriminate. ${ }^{39}$ Although there had been no congressional action codifying the agency's interpretation, Congress's subsequent actions signaled to the Court's conservatives and moderates that Congress cared about the issue and would likely override a contrary interpretation. ${ }^{40}$ These signals may have been decisive for some Justices-especially after the Reagan Administration directed the IRS to reverse the very policy to which the Court in Bob Jones was deferring. ${ }^{41}$

\section{Deference to Agencies And Post-Enactment Legislative Signaling}

In Chevron U.S.A., Inc. v. Natural Resources Defense Council, ${ }^{42}$ the Burger Court announced that it would give wide berth to dynamic statutory interpretation by agencies. The Court's reasoning was that, where there is no clear rule of law to apply in a case, and hence where policymaking is inevitable, it is more legitimate in a representative democracy for an agency to make the policy choices than it is for a court to do so. Positive political theorists consider Chevron a puzzle: Why would the Court give up opportunities to read its preferences into statutes and, instead, accept the preferences of another player in the policy game? $?^{43}$

One (and probably not the only) political justification for Chevron is suggested by the theory of post-enactment legislative signals. It is easier for Congress to send such signals to agencies (through oversight hearings, appropriations measures, and informal contacts) than to courts. By giving agencies latitude to update statutes, Chevron may have been a judicial signal to Congress that it can send at least some of its post-enactment signals through the administrative process. In tax law, for instance, interest groups, the IRS, and committee staffs often negotiate agency regulations during and after the enactment process. ${ }^{44}$

Thus, the Burger Court was sometimes willing to defer to agency interpretations the Court did not favor, when there was strong indication that the agency interpretation reflected post-enactment legislative signals. ${ }^{45}$ In School Board v.

39. Id. at 599-602; see also id. at 607 (Powell, J., concurring). The main argument of the Court's opinion was that the agency's interpretation was consistent with the statute's purpose.

40. Specifically, Chief Justice Burger (the author of the opinion) and Justices Stewart, White, Blackmun, Powell, and Stevens. Justices Brennan and Marshall probably believed in the substantive values strongly enough to support the agency notwithstanding the legislative signals.

41. Bob Jones, 461 U.S. at 574.

42. 467 U.S. 837 (1984).

43. See Linda Cohen \& Matthew Spitzer, The Chevron Puzzle, 57 LAw \& CONTEMP. PROBS. 65 (Spring 1994).

44. See Michael Livingston, Congress, the Courts, and the Code: Legislative History and the Interpretation of Tax Statutes, 69 TEX. L. REV. 819 (1991).

45. See, e.g., Bowen v. Yuckert, 482 U.S. 137, 148-52 (1987); North Haven Bd. of Educ. v. Bell, 456 U.S. 512, 530-35 (1982); Cannon v. University of Chicago, 441 U.S. 677, 686-87 \& n.7 (1979). 
Arline, ${ }^{46}$ for example, the Court interpreted the Rehabilitation Act of $1973^{47}$ to prohibit discrimination against a person afflicted with contagious tuberculosis. Neither the vague statutory language, generalized legislative history, nor precedent compelled the conservative Court to interpret the statute so liberally. ${ }^{48}$ Instead, the Court deferred to agency regulations, which "were drafted with the oversight and approval of Congress . . .."49 The history of the agency's interpretation suggested that Congress was interested in the issue, and that an override would have been likely if the Court had construed the statute more conservatively. ${ }^{50}$

III

\section{The REHNQuist COURT's Neglect OF Post-EnACTMENT Signals IN STATUTORY INTERPRETATION}

The Rehnquist Court's attitude toward post-enactment legislative signals has been markedly different from that of the Burger Court, especially in civil rights cases. In contrast to the Burger Court, the Rehnquist Court tends to treat postenactment legislative signals with open hostility, viewing subsequent legislative history with contempt, for example. ${ }^{51}$ Thus, in Public Employees Retirement System of Ohio $v$. Betts, ${ }^{52}$ the Court interpreted section 4(f)(2) of the Age Discrimination in Employment Act of $1967^{53}$ to exempt a state public employees' retirement plan from the Act. The Court reasoned that the plan was not clearly a "subterfuge," the term used in the exemption. The Court interpreted the statutory exemption broadly, notwithstanding specifically contrary language on the issue in the conference committee report for a 1978 amendment to the Act. "We have observed on more than one occasion that the interpretation given by one Congress (or a committee or Member thereof) to an earlier statute is of little assistance in discerning the meaning of that statute," 54 the Court archly rejoined. Betts is a striking example of the Rehnquist Court's position; the subsequent legislative history (a conference report) was a much stronger signal for a restrictive interpretation of the Act than subsequent history,

46. 480 U.S. $273(1987)$.

47. 29 U.S.C. $\$ 794$ (1988).

48. As argued by Justice Rehnquist in his dissenting opinion. Arline, 480 U.S. at 289-93.

49. Id. at 279 (opinion of the Court).

50. Indeed, Congress codified the result in Arline when it enacted the Civil Rights Restoration Act of 1988, Pub. L. No. 100-259, § 9, 102 Stat. 28, 31-32 (codified at 29 U.S.C. $\$ 706(8)$ (c) (1988)).

51. See Wright v. West, 112 S. Ct. 2482, 2491-92 n.9 (1992); Chapman v. United States, $111 \mathrm{~S}$. Ct. 1919, 1927 n.4 (1991); Pension Benefit Guar. Corp. v. LTV Corp., 496 U.S. 633, $649-50$ (1990); Sullivan v. Finkelstein, 496 U.S. 617, 628-29 n.8 (1990); United States v. Monsanto, 491 U.S. 600, 609-10 (1989); United States v. Taylor, 478 U.S. 326 (1988); Mackey v. Lanier Collections Agency \& Serv., 486 U.S. 825 , 838-40 (1988) (extensive discussion); Gwaltney of Smithfield v. Chesapeake Bay Found., 484 U.S. 49, 6364 n.4 (1987).

52. 492 U.S. 158 (1989).

53. 81 Stat. 602 (codified as amended at 29 U.S.C. $\$ 623(f)(2)(1988)$.

54. Betts, 492 U.S. at 168. 
usually just consisting of committee reports and member statements, which the Burger Court was willing to credit in cases like Sheffield. ${ }^{55}$ Not surprisingly, Congress overrode Betts almost immediately. ${ }^{56}$

Similarly, the Rehnquist Court has been notably unwilling to bootstrap what it believes to be erroneous judicial or agency interpretations based on legislative signals of approval or acquiescence. The leading decision is Patterson v. McLean Credit Union. ${ }^{57}$ Brenda Patterson, an African-American woman, sued her employer for harassing and firing her, allegedly for racially discriminatory reasons. Her cause of action rested on 42 U.S.C. § 1981, which assures everyone "the same right ... to make and enforce contracts . . . as is enjoyed by white citizens." 58 An issue in Patterson, raised by the Court sua sponte, was whether to overrule Runyon v. McCrary, ${ }^{59}$ a decision that interpreted section 1981 as prohibiting private as well as public discrimination in contractual relations. In Patterson, the Court unanimously affirmed Runyon, at least in principle, but splintered as to a rationale. Writing for four concurring Justices, Justice Brennan argued that in the 1970s and 1980s, Congress had sent numerous signals supportive of Runyon,$^{60}$ but the Court majority rejected the relevance of these recent legislative signals. ${ }^{61}$ The Justices' different attitudes toward recent legislative signals reflected different attitudes toward Runyon itself, which the Court majority interpreted narrowly and the concurring Justices broadly. Brenda Patterson lost her case, but within two years Congress overrode the decision. ${ }^{62}$

Both Patterson and Betts were cases in which the Court rejected longstanding agency interpretations of the statutes they were charged with enforcing, even though the agency views clearly reflected the current congressional preferences. Since 1988, the Rehnquist Court has applied Chevron more restrictively than the Burger Court did, refusing to defer to agency interpretations in conflict with statutory plain meaning. ${ }^{63}$ Again, this new attitude on the part of the Court reflects its disregard for post-enactment legislative signals.

55. Ironically, Betts may be a mild example of the Rehnquist Court's approach, because the Court did discuss the subsequent legislative history. There has been a tendency in later opinions for the Court simply to give those arguments even shorter shrift than Betts did. Sullivan, 496 U.S. at 628-29 n.8; cf. id. at 631-32 (Scalia, J., concurring in part) (refusing to join footnote 8 , because subsequent legislative history is no longer worth discussing).

56. Older Workers Benefit Protection Act, Pub. L. No. 101-433, 104 Stat. 978 (1990) (overriding Betts "to restore the original congressional intent in passing and amending the Age Discrimination in Employment Act ... . which was to prohibit discrimination against older workers in all employee benefits ...").

57. 491 U.S. 164 (1989).

58. 42 U.S.C. $\$ 1981$ (1988).

59. 427 U.S. 160 (1976).

60. Patterson, 491 U.S. at 200-305 (Brennan, J., concurring in the judgment in part and dissenting in part).

61. Id. at $175 \mathrm{n} .1$ (opinion of the Court).

62. See Civil Rights Act of 1991, Pub. L. No. 102-166, 105 Stat. 1071.

63. See Cohen \& Spitzer, supra note 43, at [34]; Thomas W. Merrill, Judicial Deference to Executive Precedent, 101 YALE L.J. 969 (1992). 
The Rehnquist Court's refusal to attend to post-enactment legislative signals reflects the Court's normative objections to the assumptions of PPT. ${ }^{64}$ On the one hand, the Court is signaling its strong preference for rule-of-law values over political expediency and its view that textual coherence is the paramount rule-oflaw value. The Court's effort to distance its "rule-of-law" decisionmaking from "political" decisionmaking may rest upon a belief that the Court's legitimacy depends upon the public's confidence that the Court is more than just another political organ of government.

On the other hand, the Court may be trying to discourage Congress from sending post-enactment signals. By trying to influence statutory interpretation through these informal channels, Congress is arguably shirking its responsibility under article $\mathrm{I}$, section 7 of the Constitution to make statutory policy only when both chambers concur and the matter is presented to the president for possible veto. ${ }^{65}$ Neither the Court nor agencies can update policy by bending clear statutory language, which reflects the wise insights of both rule-of-law and democratic theory; the Constitution requires Congress to amend the statute in such circumstances. That Congress has overridden so many of the Court's recent civil rights decisions is evidence that Congress can fulfill its constitutional role if so required. The most the Court can do is establish well-defined baselines from which Congress can write clear statutes that satisfy the "rule of law" and the "law of rules" in a democracy. ${ }^{66}$

The Rehnquist Court's rebuff to PPT's suggestion that the Court is just another player in the political game of creating statutory policy reflects a normatively attractive political philosophy, but it can be questioned from several different directions. Legal theorists might ask whether the Court's practice really delivers on the promise of its rhetoric. Do the Court's decisions merely apply a neutral rule of law? My examination of the Court's civil rights decisions between 1988 and 1992 provisionally suggests that the Rehnquist Court's civil rights decisions are not supported by any neutral rule-of-law criteria, least of all any rigorous textualism. ${ }^{67}$ Instead, $I$ read the Court's decisions as reflecting a specific ideological vision of civil rights law, influenced far more by political feelings than by sharp textual analysis. This observation presents a standing challenge to the Court to consider whether its hard-edged approach to statutory interpretation is any more legitimate than the approach of the Burger Court, whose political conservatism was softened by its pragmatic approach to statutory interpretation.

64. The critique suggested in this section has been articulated mainly by Justice Scalia; in its strongest form it is probably not accepted by a majority of the Court. See generally Eskridge, supra note 5 , at 404-14.

65. See United States v. Taylor, 487 U.S. 326, 344-46 (1988) (Scalia, J., concurring in part); see also Thompson v. Thompson, 484 U.S. 174, 192 (1988) (Scalia, J., concurring in the judgment). For analysis and critique, see William N. Eskridge, Jr. \& John Ferejohn, The Article 1, Section 7 Game, 80 GEO. L.J. 523 (1992).

66. Finley v. United States, 490 U.S. 545, 556 (1989).

67. See Eskridge, supra note 3 , at $675-80$. 
Conclusion: ThE New COURT Versus the New TheORY

One the one hand, positive political theorists might ask whether the Rehnquist Court is serving the country's interests well by ignoring postenactment legislative signals. What are the institutional advantages of the Burger Court's more responsive approach? Does the Rehnquist Court's approach place too much of a burden on the legislative agenda? Are postenactment legislative signals a relatively efficient way for our system of government to update statutes?

On the other hand, rule-of-law adherents of the Rehnquist Court might ask whether positive political theorists are endorsing positive practices (like subsequent legislative history) that are normatively indefensible. Is a Court ever sacrificing its integrity as the main rule-of-law institution when it gives interpretive weight to post-enactment signals? Is such signal-giving consistent with Congress's role under article I, section 7? Is a regime of giving and crediting post-enactment legislative signals consistent with democratic ideals? 